\title{
MORTGAGE LOANS \\ AND THEIR SOCIAL EFFECTS
}

\section{MIKOŁAJ LEWICKI, SPOŁECZNE ŻYCIE HIPOTEKI}

\author{
Marta Olcoń-Kubicka
}

Polish Academy of Sciences

In Spoleczne zycie bipoteki [The social life of a mortgage] Mikołaj Lewicki addresses the social aspects of mortgage loans. The author, a researcher at the Institute of Sociology of the University of Warsaw, specialises in the field of economic sociology, with particular emphasis on the sociology of money, the market, and finance. This book is the result of several years of research on processes related to household indebtedness and particularly financialisation. Mortgage loans, which have been available in Poland for just over two decades, have become so entrenched in social practice during this time that they have managed to influence the daily home life of borrowers and have significantly transformed the housing market and the social structure. It is these social effects of mortgage loans that Lewicki looks at in his monograph. He regards mortgage loans and the consequences of their functioning from various angles and on different scales by focusing on the phenomenon from the perspective of households, financial institutions, and the state, and by showing the different meanings of a dwelling: as a home and object of aspiration, but also as a resource subject to capitalisation.

The book has appeared at a time when the emergence of asset-based welfare is being widely discussed and there are ongoing debates in economic sociology and political economy regarding expectations and valuation practices, financialisation processes, the temporal dimensions of capital- 
ism, and assetisation. Spoteczne życie hipoteki addresses these current debates by offering new evidence and analyses regarding the Polish context.

The monograph consists of three main parts preceded by an introduction. In the introduction, Lewicki situates his approach within the sociology of markets and finance, and presents the analytical categories of "fictional expectations," derived from Jens Beckert, and of "social dispositives." These determine the direction of his further analyses. His main argument is that a mortgage loan should be recognised as a kind of dispositive that gives rise to obligations and expectations. He looks at how these are manifested at various levels of social life in separate parts of the book.

The first part ("The Experience of Living with a Mortgage") presents the debt situation from the perspective of borrowers' households. The second ("The Political Economy of Mortgage Loans") is devoted to the financialisation processes of housing and the mortgage loan market in Central, Eastern, and Southern Europe. The last part ("Stratification and the ClassCreating Power of a Mortgage Loan") focuses on socio-demographic analyses of Polish society, with particular emphasis on the financial situation of borrowers.

The first part, which is devoted to the experience of living with a mortgage, shows how a loan, or rather the indebtedness it masks, is experienced by borrowers in the practice of everyday life. In his analyses, Lewicki relies on qualitative interviews (conducted partly in cooperation with Mateusz Halawa). These analyses, which Lewicki refers to as household microsociology, focus on the expectations of borrowers: how they reason, how they experience taking a loan, and how they justify their debt situation. I appreciated Lewicki's perspective on the household, on systems of ties, and on ways of setting the rules related to domestic monetary practices, as this approach is close to my way of thinking about household economy and until recently, these matters constituted a "black box" in economic sociology.

However, Lewicki's presentation of field research outcomes left me with a feeling of wanting more. His analyses use the concept of "orders of worth" advanced by Luc Boltanski and Laurent Thévenot, representatives of the French pragmatic school. Lewicki's manner of discussing the individual situations of borrowers, with the classification of their justifications in the repertoire of communities (inspired, domestic, fame, industrial, and market), means that these situations are not brought sufficiently to the fore. The exception here is the civic community, which Lewicki reconstructed from an analysis of the discourse concerning borrowers who took mortgages in Swiss francs (i.e., the "franc borrowers"). Lewicki's presentation 
of the politicising of mortgage loans through the franc borrowers' movements is in-depth and convincing.

The author's most coherent and exhaustive arguments appear in the second, most extensive part of the book, in regard to the field of political economy. He considers the processes of financialisation, that is, the growing importance of the financial sector for the functioning of the economy and households. These analyses are inspired by Manuel Aalbers's works showing the links between the expansion of financial markets and the real estate market. Lewicki reconstructs the process of households becoming "mortgaged," that is, of their becoming connected to the financial sector, and shows how the mortgage loan has become a particularly important instrument in the process of financialisation.

He conducts his analyses from a comparative perspective. His reflections on the course of housing financialisation processes focus on selected countries of Central, Eastern, and Southern Europe, that is, on Spain, Hungary, and Croatia. Comparative analysis makes it possible to show the specificity of the financial sector in individual countries; Lewicki shows how local conditions and dominant ideologies have made home ownership and private investments a social norm and have been grounded in practice. At the same time, he shows local differences in forms of housing capitalism, with the impact of mortgage loans on the situation of households, and the kinds of economic crises that have been experienced in different regions of Europe.

In this context, he considers the specific situation of Poland, a country characterised by a familial model of housing capitalism. The model involves a high percentage of private property (due to the privatisation of the housing stock in the 1990s) and the importance of intergenerational transfers for home buyers. These conditions are accompanied by a low percentage of apartments for rent and of social housing. Lewicki shows how the dissemination and democratisation of credit occurred and took a central place in the housing financing system after 2000. He looks at the role of the state in this process and its changing attitude to regulatory issues in regard to foreign-currency loans or the amount of a buyer's downpayment.

What I found of particular interest in this part was the author's showing how the spread of mortgage loans appeared along with the state's simultaneous elimination of its housing policies and support of market solutions. State-run programmes such as "Housing for the Young" or "The Family in Its Own Home" became instruments for the active development of housing ownership through mortgage loans. In this context, Lewicki's 
analyses constitute an important voice in the current debate (which was recently joined, inter alia, by Łukasz Pawłowski's book Druga fala prywatyzacji [A second wave of privatisation]) on the withdrawal of the state from public services related to social security.

This part of the book is the most informative. The author recounts for the readers the history of financialisation processes in particular regions of Europe, provides data, and uses it effectively in comparative analyses. His explanations are solid and credible, and his analyses are well grounded in facts and literature. He familiarises readers with the current debates related to the growing importance of housing in financialisation processes and proposes his own interpretations, with particular emphasis on the situation in Poland. Viewing Poland's situation in comparison to other models of housing capitalism allows us to better understand the economic, social, and cultural processes associated with the spread of mortgage credit. Lewicki carries out his analyses in an orderly and exhaustive manner, and this is the main virtue of this part of the book. He is competent and skilful in dealing with issues of political economy and clearly feels at ease with the subject as he has published articles in the area before. This part of the book is the most consistent and could be viewed as a complete entity in itself.

The last part of the book (which was co-written with Krzysztof Tymicki) introduces another direction of thinking about the social consequences of mortgages. It is focused on considerations on the class and stratification dimension of mortgage loans. The researchers decided to examine the financial situation of borrowers (including those who have loans in Swiss francs) against the financial situation of home owners and tenants. For this purpose, they analysed data from research conducted by the Central Statistical Office (Household Budget Research 2016), and focused, among other things, on such aspects as living space, income and its sources, subjective measures of consumption comfort, and the structure of household expenses. On the basis of their analyses, they concluded that borrowers were better situated: they had achieved higher social status and had greater life chances than the rest of the population. The intention of the authors was to show the selection and classification properties of the mortgage loan, which divides households into "winners" and "losers."

In their reflections, the authors introduce an extremely important topic: the diversification of wealth distribution and the role of a mortgage in individual enrichment. In this way, they join the current debates on the rising importance of wealth - as opposed to income or profession - in social stratification. This development is important for understanding the pro- 
cesses shaping inequality, and is particularly important in Poland, where, as the NBP research cited by Lewicki shows, the main source of assets and wealth is not income from work but from running a business. More empirical research is certainly needed on this issue. For instance, in further analyses, the inclusion of data on social background, inheritance, and access to family wealth would help highlight the quest for social mobility through a mortgage.

The chapters on stratification and classifications related to mortgages are strictly empirical in nature. The authors draw conclusions on the basis of their analyses, but by no means place them in the wider discussion on capital, wealth, inequality, and social classes initiated recently by Thomas Piketty in Capital in the Twenty-First Century. Apart from short references to the concepts of Weber, Bourdieu, or Lamont, I missed a discussion of the current theories of social class and housing that point to the importance of assets and housing ownership in class stratification, as undertaken, for example, by Mike Savage and his team (Savage 2015). The authors' omission to set their conclusions in the context of the broader literature is a weakness in these chapters. Of course, consideration of the subject of class in Poland is not an easy task; there is still no agreement among researchers as to who belongs to the middle class in Poland, or whether a middle class exists at all, or whether the majority only aspire to belong. All this is especially the case if we compare the authors' criteria for assigning people to the upper or middle class with the criteria applied to classes in Western societies of well-established late capitalism. It emerges that we are dealing not with the upper and middle class but at most with the upper middle class and middle class or those aspiring to the middle class, who by striving to own a home by means of a loan are trying to raise their position. Nevertheless, the conclusions proposed by Lewicki and Tymicki will allow researchers dealing with social stratification to start a discussion on the connection between having a mortgage and social position.

In conclusion, Lewicki returns to the discussion of the mortgage loan as a social dispositive generating a number of effects in various areas. He recalls how individual actors in the housing market - households, the state, and financial institutions - formulate their expectations for the future, and how those expectations contribute to the development of the mortgage market. Again, he devotes the most space to aspects related to the political economy of mortgages, this time focusing on the institutional changes of capitalism in Poland and engaging in discussions with Polish researchers in this field. 
Due to my own research interests, my attention was drawn in the conclusions to essential topics that Lewicki had previously only mentioned in passing, such as the role of intergenerational transfers in obtaining property, the deepening inequalities based on property differences, or the emerging culture of rent. By drawing this picture, Lewicki once again proves his ability to see the entire range of social conditions and the consequences of mortgages. However, this loaded ending, which is saturated with many extremely important topics, raises more questions and hypotheses than it gives answers. In this sense, it leaves the reader wanting more and with open questions for reflection, for example, on the subject of rentierism, that is, thinking about a dwelling in terms of its being a resource subject to capitalisation, generating passive income, and offering financial freedom, and thus deepening the financial difference between home owners and tenants. Lewicki writes about the "winners" and "losers" of the processes taking place on the mortgage market. The question is to what extent this game and its rules are recognised by the actors participating in it. To what extent should the state intervene in this game in which some have increased opportunities for social mobility, while others are deprived of it? Lewicki in fact does not mention the cadastral tax, but thinking about various instruments of fiscal policy will be necessary if Poland is to move towards asset-based welfare to the same degree as Western countries dominated by the liberal regime of the housing market.

What draws the reader's attention is the fact that the various parts of the book seem to constitute separate entities, written in different language. This is a consequence of the ambitious choice of a broad view of the social aspects of mortgages and to some extent it also results from the fact that each of the individual parts selects a different object of analysis, while referring to different debates and theoretical inspirations. Similarly, the diversification of the data leads the analysis in different directions. Lewicki himself draws attention to these limitations: households, with their internal complexity of relations and rules of operation, which were reconstructed and discussed on the basis of qualitative interviews in the first part, become once again a black box in the third part, which is based on statistical data. There are no internal inequalities, including gender ones; there are no differences in access to family resources, and the life cycle is not visible. In addition, the breadth of gaze causes both the language and the argumentation in the individual parts to change, while the main argument concerning expectations has a different resonance in them. After the first reading, the reason for the juxtaposition of various subjects remains unclear; the reader 
is left to guess and to navigate between the introduction and the ending to recreate it. This is undoubtedly a reading that requires concentration.

Both the thematic diversity and the form mean that the recipients of individual parts will probably be different readers. The first part will attract more people with an interest in the sociology of everyday life, household relations, and valuation practices. The second will find readers who are interested not only in economic sociology or political economy, but also in finance, housing, and public politics. The third should be of interest to researchers who study stratification, social classes, and inequality.

In summary, Spoleczne $\dot{z} y c i e$ hipoteki is a dense, extensive, and multi-issue monograph on the functioning of mortgage loans in Poland. It is certainly a necessary and useful book for understanding the impact of this instrument on social life. It presents the phenomenon in a broad fashion, while simultaneously familiarising the Polish reader with the current debates in economic sociology and political economy in the area. In this context, Lewicki's voice is important because his deliberations on Poland provide evidence enabling further comparative analyses with countries from Central, Eastern, and Western Europe.

This book, which crowns years of research by the author, is at the same time an open project. It is an invitation to discussion, and its major advantage is that it sets directions for further research. Having been awarded the Ludwik Krzywicki Prize at the Faculty of Humanities and Social Sciences of the Polish Academy of Sciences in the field of sociology, this book has already made its mark and can be expected to take a place in the academic debate.

Translated by Michelle Granas

Bibliography:

/// Lewicki M. 2019. Społeçne życie bipoteki, Wydawnictwo Naukowe Scholar.

/// Pawłowski Ł. 2020. Druga fala prywatyzacji: niezamierzone skutki rzadón PiS, Fundacja Kultura Liberalna.

/// Piketty T. 2014. Capital in the Twenty-First Century, Belknap.

/// Savage M. 2015. Social Class in the 21st Century, Pelican. 
/// Marta Olcoń-Kubicka - economic sociologist and researcher in the Max Planck Partner Group for the Sociology of Economic Life at the Institute of Philosophy and Sociology of the Polish Academy of Sciences. Her work focuses on cultural analyses of economic life and on ethnographic research into money practices in households. She was a principal investigator in the project "Practices of Handling Money in Close Relationships in Young Family Households" (2014-2017). She is currently leading the research project "Intergenerational Transactions: Relational Work and Moral Frames in Transfers of Wealth from Parents to Their Adult Children" (2019-2021).

ORCID: https://orcid.org/0000-0003-3080-7166

E-mail:marta.olcon@gmail.com 